\begin{tabular}{c} 
Volume and Issues Obtainable at Center for Sustainability Research and Consultancy \\
Review of Politics and Public Policy in Emerging Economies \\
ISSN: $2708-3829 \&($ E):2708-356X \\
Volume 3: No. 1, June 2021 \\
CSRC \\
Journal homepage: www.publishing.globalcsrc.org/rope \\
\hline
\end{tabular}

\title{
Legal, Administrative and Judicial Framework in Pakistan to Combat Tax Evasion and Money Laundering: An Analytical Study
}

Aamir Khan, Advocate at High Court Bahawalpur, Pakistan

*Naureen Akhtar, University Gillani Law College, Bahauddin Zakariya University, Multan,

Pakistan

*Corresponding author's email: naureen.akhtar@bzu.edu.pk

\begin{tabular}{l} 
ARTICLEDETAILS \\
\hline History \\
Revised format: May 2021 \\
Available Online: Jun 2021 \\
Keywords \\
Tax Evasion, Money \\
Laundering, Legal \\
Framework, Administrative \\
Framework and Judicial \\
Framework.
\end{tabular}

JEL Classification

H2O, H26

\begin{abstract}
Purpose: The main objective of this research paper is to look at Pakistan's legal, administrative, and judicial framework in terms of countering money laundering and tax evasion. Money laundering and tax evasion are two financial crimes that have been linked, either directly or indirectly, to one other. Money laundering was formerly solely associated with the crimes of narcotics trafficking and terrorism financing. At present, it has been also associated with tax evasion.

Methodology: The framework regarding tax evasion and money laundering is varied. In Pakistan, two different mechanisms exist to combat both crimes. This article analytically studies the parliamentary statutes and ordinance, the working of investigating and prosecuting agencies and judicature structure concerning tax evasion and money laundering in Pakistan.

Findings: This article concludes that the problem of tax evasion and money launder are causing financial instability in Pakistan. There is an urgent need of revamping the current tax administration to detect tax evasion and frauds.

Implication: this article recommends potential reforms in the existing legal, administrative and judicial framework to control and curb both crimes more effectively.
\end{abstract}

(C)2021The authors, under a Creative Commons AttributionNonCommercial 4.0

\footnotetext{
Recommended citation: Khan, A. and Akhtar, N. (2021). Legal, Administrative and Judicial Framework in Pakistan to Combat Tax Evasion and Money Laundering: An Analytical Study. Review of Politics and Public Policyin Emerging Economies, 3(1) 69-77.
}

\section{Introduction}

In the modern global economic system, tax is a major source of revenue for every country. A state cannot provide public services to its citizens if they try to avoid or evade taxes and launder money. Tax evasion and money laundering cause loss of revenue as well as impacts the flow of money. It may also jeopardise a nation's economic integration and social progress. In the new economic system, citizens voluntarily pay their taxes on their incomes from services and profits 
from businesses.

Tax evasion is a worldwide issue, and Pakistan is no exception. The rate of tax evasion in Pakistan is much greater than the rate of revenue collection. Pakistan has been forced to rely on external debt due to tax evasion. Pakistan has struggled to develop and update its tax revenue management system since its inception. Consequently, in comparison to certain other South Asian nations, Pakistan's "tax to GDP" ratio is incredibly low (Kamal, 2021).

Pakistan has also been included to the Financial Action Task Force's grey \& blacklists multiple times owing to failures in combating money laundering and tax evasion. To get out of the grey list of this international watchdog agency, Pakistan is fighting on multiple fronts that include money laundering and its predicated offences such as terror financing, corruption, cybercrimes and also smuggling (Babar, 2021).

The issue of money laundering is causing loss Pakistan's economy a loss of billions of dollars every year. According to a study released by the US State Department in 2017, trade-based money laundering costs Pakistan more than $\$ 10$ billion per year. The money launderer uses a legitimate trade company to cover their illegal profits from their illicit means in this form of money laundering (Iqbal, 2017).

The primary objective of this article is to conduct an in-depth analysis of the issue of money laundering and tax evasion in Pakistan, which is exacerbated by legal ambiguities in the legislative, administrative, and judicial framework. Furthermore, it also looks into the historical evolution of laws related to both crimes. Additionally, it critically analyzes the provisions relating to tax evasion in Income Tax Ordinance, 2001and other relevant laws.

Further on, it explores into provisions related the offence of money laundering under "AntiMoney Laundering Act". Moreover, this article also critically examines the functioning of different administrative agencies combating both crimes. It also discusses the existing judicial structure concerning both crimes. Finally, this study also emphasizes the need for reforms in the legislative, administrative, and judicial framework to fight both crimes more effectively.

\section{The Problem of Tax Evasion and Money Laundering in Pakistan}

Informal economy and evasion of tax have been major source of concern in Pakistan. The persistently low tax base, low tax elasticity, and buoyancy, as well as the resulting growing fiscal deficit, are causes for concern. Not only economists, but also sociologists, political leaders, policymakers, nongovernmental organizations, and the public, have recently expressed strong interest in the scale of Pakistan's underground economy and tax evasion (Iqbal, 2012).

Pakistan's substandard taxation is primarily due to tax evasion. Tax dodging isn't exactly a new issue in Pakistan. The informal economy and tax evasion are intimately connected to the state's economy, and also the trouble is now only getting worse. The overall amount of tax evasion in 1973, according to some figures, was around 1.5 billion rupees. The amount had climbed to 152 billion rupees by 1996. The government is losing 7 billion rupees a day due to tax evasion, according to a 2012 study by Pakistan's National Accountability Bureau (Kamal, 2019).

As tax evasion is a predicate offence of money laundering, the person involved in tax evasion moves its money originated from tax evasion to another place. People who evade taxes attempts to hide it from the authorities by employing different money laundering techniques. According to a research conducted by "US State Department's International Narcotics Control Strategy", trade-based money laundering costs the global community tens of billions of dollars each year, with China, Russia, Mexico, and India accounting for the top four sources of illicit 
money outflows. As a result of this activity, Pakistan loses roughly 10 billion dollars every year (Zahid, 2019).

The "Financial Action Task Force", the world's anti-money laundering regulator, also wants its member nations to address strategic flaws in their anti-money laundering, anti-terrorist financing, and anti-proliferation funding programs. If a country fails to meet these requirements, it is put on the FATF's "jurisdiction under enhanced surveillance," or "grey list." On these lists, states agree to correct their strategic vulnerabilities within a set time period. Under the grey list, FATF and its regional organizations continue to collaborate with a number of countries and report on their development. Due to its weak anti-money laundering regulations, the FATF has put Pakistan on its grey and blacklists numerous times. In order to get off the FATF grey list, Pakistan is fighting tax evasion, money laundering, terror financing, corruption, smuggling, and cybercrime (FATF, 2021).

\section{Functioning of Tax Administration in Pakistan}

In a democratic society, tax is a cost of living that citizens must pay to fund economic growth and planning. It is the government's taxation of commodities, companies, individuals, and communities to raise money in the land. Pakistan's federal tax structure is similar to that of other countries. Pakistan's tax collection is a major economic issue. Bad management in tax offices, inappropriate conduct by tax officials, confusing and confusing tax rules, a lack of public education about the tax system, misuse by the tax authorities, and, most significantly, individual's reluctance to pay taxes all contribute to the dysfunctional tax system (Nadeem, 2020).

The foundations of Pakistan's major tax administration body, the Federal Board of Revenue, dates all the way back to 1924, when the Central Board of Revenue was established by 1924 Act of Central Board of Revenue. A full-fledged "Revenue Division" in 1944 was created by Ministry of Finance. The Administrative Reform Committee proposed that the FBR be placed to the Finance ministry on August 31, 1960, and this structure lasted until August 31, 1960. In 1974, the Board and its functions were improved even further. As a result, the ex-officio Chairman of the FBR, Secretary Finance, was relieved of his duties, and the position of the Chairman was created. After the FBR Act was passed in July 2007, the CBR was renamed the FBR (FBR, 2021).

Pakistan's tax administration is lacking in highly educated, experienced, well-trained, and impartial tax officials. The Federal Board of Revenue is extremely corrupt, deceptive, and unwilling to cooperate. Similarly, taxpayer's tax assessment collusion with tax authorities encourages tax evasion. Because of their discretionary authority, tax officers are very likely to collude with taxpayers in return for bribes and other benefits. Furthermore, in order to increase revenue, Pakistani governments suggest tax amnesty and incentives. Tax evaders and money launderers profit from these opportunities (Awan, 2014).

\section{Historical Evolution of Laws relating to Tax Evasion and Money Laundering}

The Income Tax Act of 1922 is the foundation of Pakistan's tax laws. This act was embraced and applied across Pakistan after independence, except for a few special areas. In 1979, some new complexities arose, including tax evasion. The Income Tax Ordinance of 1979 was approved and went into force on July 1, 1979, to counter tax evasion and fake tax records (Qazi, 2009).

Tax Ordinance 2001, which repealed the Income Tax Ordinance of 1979, was enacted in 2002. On July 1, 2002, the Ordinance took effect. There are 241 sections, 13 chapters, and 7 schedules in this Legislation. This legislation takes precedence over all other income tax laws in Pakistan. This legislation applies across Pakistan, with the exception of the ex-FATA zones, since Article 
246 and 247(3) of the Pakistani Constitution prohibit the execution of any law approved by Parliament (Qazi, 2009).

Pakistan's anti-money laundering legislation, likewise, has a short history. Pakistan has struggled with money laundering since its inception, and it is still unable to effectively fight it, as well as related crimes like tax evasion and terror financing. When Pakistan established the Financial Monitoring Unit in December 2007, it declared money laundering to be a crime. The Pakistani Parliament passed the Anti-Money Laundering Ordinance in 2007. Following that, Parliament passed the Anti-Money Laundering Act 2010, also known as the AMLA, in 2010 to more effectively combat money laundering (Recorder, 2017).

\section{Legislative Framework: Income Tax Ordinance, 2001 and Anti Money Laundering Act, 2010}

Income Tax Ordinance 2001 oversees income tax collection and regulates the offences relating to tax evasion. It prescribes methods of detection of hidden income of tax payers. This ordinance expressly declares evasion of tax as an offence. However, it must be noted, however, that Income Tax Ordinance of 2001 lacks a definition of that word "tax evasion." The ordinance does not include a word that would clarify the components of the tax evasion offence. This statute's primary objective is tax collection, and it specifies only a limited number of taxable income of individuals and corporations. It provides criteria and process of collection of taxes and procedure for resolution of any dispute arising during tax collection. The Ordinance is not primarily concerned with the source of income of an individual or a company. The Ordinance does not contain any provisions that could enable the tax officials to further scrutinize the source of income of a person.

Overseas money inflows into Pakistan are dealt with in Section 111 (1) of Income Tax Ordinance. "Unknown earnings or assets" are governed by Section 111 (1) of Income Tax Ordinance. The amount would be levied to an individual's tax liability if he fails to explain to the Commissioner the presence and source of funding ascribed to his income statement, any valued item, or any loss experienced. Clause (1) of section 111, on the other hand, does not applicable to any overseas financial transactions performed via legitimate methods up to a limit of 5 million rupees, according to section 111 (4).

In the context of the preceding section, this article says that this provision of the Income Tax Ordinance, 2001 facilitates money laundering in Pakistan. This allows for the unchecked entry of illicit funds into Pakistan. This also jeopardises Pakistan's efforts to combat money laundering and remove the country off Financial Action Task Force's grey list. It is also damaging the efforts of diplomatic authorities to get into treaties with Tax Havens, who will certainly object to such laws and will not show a willingness to agree with Pakistan. Therefore, it would be very essential to repeal such a provision that is allowing illicit money into Pakistan.

Sections 192 to 200 of Income Tax Ordinance, 2001, include measures relating to the crime of tax evasion. If the amount of income tax avoided exceeds Rs. 10 million, Section 192 allows an individual to be prosecuted for making a false statement after scrutiny. Whereas provision 194 applies to unauthorised use of a National Identity Card Number when volume of evaded tax is more than "10 million" rupees.

Furthermore, s.192 deals with the concealment of any transaction, sale, reception, or manufacture of any entities that the tax is due. It is not particularly concerned with type and source of business that is concealing the audit trail, revenues, or manufacturing that is subject to taxation. Therefore, if a person is involved in money laundering as well as tax evasion, he will only be prosecuted for 
the offence of tax evasion under this section. Therefore, this article suggests that there is a need for amendment in the above-mentioned to prosecute the person involved in both crimes.

In a landmark judgement titled "CIT v Ely Lilly \& Others" (2009), Supreme Court declared that "authorities in Pakistan have continued to fail to regulate any tax structure that has been adequately debated and passed by parliament," referring to lawfulness and utility of Income Tax Ordinance, 2001. The 2001 Income Tax Ordinance was inadequately drafted, and it has been changed over 2000 times in previous decade, resulting in numerous litigation and misunderstandings."

On the other hand, the Anti-Money Laundering Act of 2010 focuses on identifying and prohibiting the mechanism by which assets obtained through criminal activity are transferred to a normal financial system and banking. Its main concern is a criminal enterprise.

Section three of AMLA defines the word "money laundering" as follows:

- If an individual does any of the following, he or she is accused of money laundering:

- Acquire, utilize, hold, conceal, or shift any asset that has been received as a result of a criminal activity.

- With knowledge that the asset would be the product of a criminal activity, covers or conceals the source, position, mobility, and type of the asset, including its genuine title.

- Owns or holds the property on behest of someone who knows it is the product of a crime, or colludes to do so.

The term of money laundering set out in Section 3 of AMLA, 2010 is quite broad and encompasses every aspect of the money laundering offence. However, the phrase "predicate crime" is not defined under this Law. A predicate is an offence that is a source offence for money laundering. The criminal proceeds (known as predicate offences) of any other crime are laundered through the process of money laundering to get benefit from such illegal money (Britannica, 2021). For instance, tax evasion has been declared as a designated predicate offence for money laundering by FATF in 2012 (FATF, 2012). As a result, this article underlines the need of Anti Money Laundering Act of 2010 outlining all predicate offences.

The legislation on penalty is included in section 4 of the Act, as well as the minimum term for laundering money is 1 year, with a maximum term of ten years. A penalty of up to one million rupees may also be imposed on the individual. Any asset utilized in the laundering scheme may be seized as well. As per this article, the minimum sentence per "section 4" is insufficient for a serious offense like laundering money. Lawbreakers are more likely to flee court and secure bail if the minimum sentence is applied. As a result, this essay proposes for a three-year minimum penalty for laundering money.

Suspicious Transaction Reports, or STRs, are specified in Section 7 of the AMLA. This report discusses any suspicious transaction or sequence of transactions that include dirty money obtained through illegal activity, transactions that appear to have no apparent lawful intent or transactions that involve terror funding. Banking Institutions are supposed to submit reports of any fraudulent transactions under this clause by reviewing the individual's FBR information. When there has been a suspicion of the associated violations under Schedule of the AML Act, 2010, STRs must always be notified.

The effective execution of section 7 of the Anti-Money Laundering Act, however, is dependent on Pakistan's banking sector's cooperation, according to this article. Pakistani banking institutions are notorious for their confidentiality. In Pakistan, banks are allowed by law not to reveal any financial information about their customers. The law forbids them from disclosing any information about their clients' transactions (Haq, 2019). 
These restrictions are incorporated into sections 5 and 6 of the Banker's Books Evidence Act, 1962, section 33A of the Banking Companies Ordinance, 1962, and the State Bank of Pakistan's Regulations, section 9 of the Protection of Economic Reforms Act, 1992, sections 46A, 46B of the State Bank Act, 1956, and section 5 of the Foreign Currency (Protection) Ordinance, 2001 (Haq, 2019). Thus, it is highly recommended that to amend these laws to reduce the level of bank secrecy in Pakistan and to strictly deal with the suspicious transaction in Pakistan.

\section{Administrative Framework}

This article examines the present administrative framework for money laundering and tax evasion in order to emphasize the capabilities and duties of various money laundering and tax evasion investigative and prosecution authorities.

D.G. I\&I is the primary investigating authority in case of tax evasion in Pakistan. It works under the supervision of the Federal Board of Revenue. It was established under Sales Tax Act, 1990. This authority is headed by the Director General Intelligence and Investigation. He is appointed by the FBR. This agency performs various functions including investigation of fiscal crimes. The key functions include:

- Link with all of the country's databases.

- To fight against non-filing or under-filing of tax returns, data is cross-matched.

- Taking care of any complaints referred by the FBR Chairman

- One of its main responsibilities is to perform any preliminary investigation, as recommended by Board, to prevent loss of revenue.

- To gather information on tax avoidance and tax evaders' collusion with tax collectors, financial scam, and revenue outflows.

Since it wasn't permitted to deal with situations in which an individual was accused with the both money laundering and tax evasion, this agency has previously failed to investigate tax evaders and others involved in tax scams and frauds. Meanwhile, it is now registering complaints under the 2010 Anti-Money Laundering Act. The FBR has recorded 120 total cases under Anti Money Laundering Act 2010, including income of around Rs. 88.4 billion, in order to meet with FATF requirements (Haider, 2020).

The Anti-Money Laundering Act, 2010 explains an investigatory or prosecution institution as "National Accountability Bureau", "Federal Investigating Agency", "Anti-Narcotics Force", and other "agency", as defined in section (2) Interpretation's clause (j) (j). Those authorities are in charge of handling money laundering, as defined in section 3 of the act, and every other offense. Another administrative authority related to fiscal crimes is constituted under section 6 of AML, 2010 is Financial Monitoring Unit. This is an autonomy body that is empowered by Federal government to makes independent decisions. The Federal Government appoints a DirectorGeneral who heads FMU. The key functions of FMU includes:

- It has the authority to request suspicious transaction reports from any financial institution.

- It has the authority to seek any documentation or financial related information to an unusual activity from any person or organization, and also to instruct any investigative agency to undertake an inquiry or investigation into the suspected transactions under any applicable legislation.

- It does have the power to work with foreign intelligence services to provide financial input regarding offences committed under this law and to represents Pakistan on a worldwide level.

- It is authorized to take database of any other agency for national security reasons.

Role of "Financial Intelligence Unit" is crucial in combating both tax evasion and money laundering. It enables disparate fiscal crime investigating and prosecution departments that 
perform various roles to exchange information to combat these crimes. Linking all of the FMU's databases under the AMLA and the FBR's databases under the Federal Board of Revenue Act of 2007, maybe extremely useful in capturing tax evaders who are also involved in money laundering.

This article, on the other hand, claims that the current administrative framework for combatting money laundering and tax evasion is ineffective and that its power is not centralised under one body. The power of these investigating agencies including FIA, Nab, and D.G. I\&I are scattered. These all agencies operate under different laws and different jurisdictions. Their statutes do not recognize these crimes as primary investigation target.

On a limited scale, there is cooperation between various crime investigating agencies dealing with tax evasion and money laundering, however this coordination fails because these agencies operate under different laws. This article suggests that, there is a need of establishing a special investigating agency in order to apprehend, prosecute, and successfully convict the tax evaders and money launders. This new agency should be equipped with all modern-day technology, well trained staff and reasonable funding.

\section{Judicial Framework}

The current tax appellate mechanism is inefficient, outdated, and utterly ineffective, with a lot of incompetence and long wait times. The budgetary conflicts between the state and the taxpayers must be resolved quickly for the system to function properly. It necessitates a thorough reorganization and redesign. A four-tier appeal structure is in place under Pakistani tax laws (Bukhari, 2019).

Sections 192 to 200 of Income Tax Ordinance of 2001 explain the restrictions against tax evasion. A "special judge" is assigned within section 203 of "Income Tax Ordinance" to prosecute such offenses. The "Federal Government" also determines geographical authority as well as judges' numbers. Under section 185 of "Customs Act of 1969" the "Federal Government" may also proclaim that a special court would be established to prosecute breaches of the decision.

Money laundering is not specified as a felony in Income Tax Ordinance or Schedule to the Income Tax Ordinance, according to this article. As a consequence, Special Judge court will not be allowed to hear the case. When a person is accused of both money laundering and tax evasion, case gets more problematic since the charges cannot be brought in the very same court.

As a consequence, the judicial system set up by the Income Tax Ordinance of 2001 and the Sales Tax Act of 1990 is insufficient. There is no court's system in place to deal with situations of tax evasion. Tax evasion, like any other crime, has a negative impact on the economy and social values of a country. It will not be enough to appoint a "Special Judge" to prevent tax evasion. Pakistan's judicial system urgently needs to be revamped, with "National Tax Courts" being established aim of providing immediate justice to the nation's lawful and genuine tax paying citizens while also trying to punish tax evaders.

Similarly, Anti-Money Laundering Act does not create a separate judicial system to hear money laundering matters. The Courts of Session is given authority to trial the crimes outlined in Act under Section 20 of AMLA. The Courts of Session's power is established under Code of Criminal Procedure of 1898.

The AMLA, 2010, section 20(a) authorises a court other than a Session Court adjudicating a predicated crime (tax evasion) of laundering money to additionally trial money laundering crime. 
This creates a direct relationship between money laundering courts and tax evasion and money laundering courts.

Section 21 of Act declares all crimes punished under the AMLA non-cognizable and nonbailable. According to Section 21, judge may only take cognizance of a complaint submitted by investigating officer and any other official authorised. The investigating officer or any other authorised official, on the other side, first should acquire clearance from the appropriate regulatory authority before submitting a charge against a financial company or an individual accused of money laundering.

The above-mentioned clause, according to this source, merely needs a government employee to be a complainant and forbids a private individual from reporting the crime. Furthermore, when a state official becomes a complainant in these cases, the impartiality and integrity of the trial process are expected to be undermined.

The courts under AMLA, 2010 are of ordinary nature. The biggest issue with these courts is that they are in charge for prosecuting the predicate crime of money laundering, which is handled by other similar courts. This article argues that creating two separate courts for same purpose is both waste of time and resources. Therefore, there is a need of well-structured judicial setup in order to try a person involved in tax evasion and money laundering. As a result, this well-structured judicial system led by Pakistan's Supreme Court will be only serving the state's and people's best interests.

\section{Conclusion and Recommendations}

This article concludes that the problem of tax evasion and money launder are causing financial instability in Pakistan. There is an urgent need of revamping the current tax administration to detect tax evasion and frauds. Legislators and reformers must pay close attention to the current legal, administrative, and judicial system. The current system's ability to combat tax evasion and money laundering is hampered by a number of legal complexities. These legal loopholes make it difficult for the state to prosecute these wealthy criminals. These criminals are still able to get away with their crimes by exploiting legal flaws.

\section{References}

Kamal, A. (2021). "Tax Evasion in Pakistan: Determinants and Requisite Policy Interventions". European Online Journal of Natural and Social Sciences 2019; Retrieved 15 April 2021, from.

Baabar, M. (2021). "FATF Action Plan Near Completion". The News. Retrieved 15 April 2021, from https://www.thenews.com.pk/print/819400-fatf-action-plan-near-completion.

Iqbal, A. (2017). "Pakistan Loses \$10bn A Year to Money Laundering". Dawn. Retrieved 15 April 2021, from https://www.dawn.com/news/1318697/pakistan-loses-10bn-a-year-tomoney-laundering.

Iqbal, Z. (2012). "The Underground Economy and Tax Evasion in Pakistan: A Fresh Assessment". Pakistan Institute of Development of Economics. Retrieved 19 April 2021, from.

Kamal, A. (2019). Tax Evasion in Pakistan: Determinants and Requisite Policy Interventions. European Online Journal of Natural and Social Sciences 2019; 185-199.

Zahid, M. (2019). "Money Laundering and Its Impact on Pak Economy." Daily Times. Retrieved 19 April 2021, from https://dailytimes.com.pk/355107/money-laundering-and-its-impacton-pak-economy/.

Task Force, F. (2021). "FATF Countries-Pakistan". Financial Action Task Force. Retrieved 19 April 2021, from http://www.fatf-gafi.org/countries/\#Pakistan.

Nadeem, M. (2020). “Tax system of Pakistan”. The Nation. Retrieved 19 April 2021, from 
https://nation.com.pk/22-Dec-2020/tax-system-of-pakistan.

Revenue, F. (2021). "Introduction to FBR". Federal Board of Revenue Government of Pakistan. Fbr.gov.pk. Retrieved 19 April 2021, from https://fbr.gov.pk/introduction-fbr/131167/57.

Awan, Dr. Abdul Ghafoor. (2014). "The Determinants of Tax Evasion in Pakistan-A Case Study of Pakistan". International Journal of Development and Economic Sustainability 50-69.

Qazi, N. (2009). “A Historical Background of Tax Laws in Pakistan”. Retrieved April 19, 2021, from http://noumanqazi.blogspot.com/2009/12/historical-background-of-tax-laws in.html

Recorder, B. (2017). "Anti-Money Laundering Regulations and Fiscal Laws". Business Recorder. Fp.brecorder.com. Retrieved 19 April 2021, from https://fp.brecorder.com/2017/09/20170909216136/.

Task Force, F. (2012). "Designated Categories of Offences." FATF Publications. Fatf-gafi.org. Retrieved 20 April 2021, from https://www.fatf-gafi.org/glossary/d-i/.

Britannica. (2021). "Predicate Offense Law." Encyclopedia Britannica. Retrieved 20 April 2021, from https://www.britannica.com/topic/predicate-offense.

Haq, Dr Ikramul. (2019). "Banking Secrecy and Benami Law". Daily Times. Retrieved 20 April 2021, from https://dailytimes.com.pk/373878/banking-secrecy-and-benami-law/.

FBR. (2021). "Director General (Intelligence and Investigation - Inland Revenue)". FBR. Retrieved 20 April 2021 from. https://www.fbr.gov.pk/about-i-i-ir/592.

Haider, M. (2020). "FBR Registers 119 Complaints Under Anti-Money Laundering Act 2010". The News. Retrieved 22 April 2021, from https://www.thenews.com.pk/print/763655-fbrregisters-119-complaints-under-anti-money-laundering-act-2010.

Bukhari, H. (2019). "Reforming the Tax Appellate System". The News. Retrieved 22 April 2021, from https://www.thenews.com.pk/tns/detail/568329-reforming-tax-appellate-system. 